\title{
Serum apelin and resistin levels in patients with impaired fasting glucose, impaired glucose tolerance, type 2 diabetes, and metabolic syndrome
}

\author{
Erhan Onalan (10), Burkay Yakar ${ }^{(2)}$, Abdullah Onder Barım³, Mehmet Ferit Gursu (i)3 \\ ${ }^{1}$ Department of Internal Medicine, Faculty of Medicine, Firat University, Elazig, Turkey \\ ${ }^{2}$ Deparment of Family Medicine, Faculty of Medicine, Firat University, Elazig, Turkey \\ ${ }^{3}$ Department of Biochemistry, Faculty of Medicine, Firat University, Elazig, Turkey
}

\begin{abstract}
Introduction: The aim of this study was to investigate serum apelin and resistin levels in patients with impaired fasting glucose, impaired glucose tolerance, type 2 diabetes and metabolic syndrome.

Material and methods: The study comprised 18 patients with type 2 diabetes mellitus (T2DM) (nine females, nine males), 18 patients with impaired fasting glucose (IFG) (nine females, nine males), 18 patients with impaired glucose tolerance (IGT) (nine females, nine males), 18 patients with metabolic syndrome (MeS) (nine females, nine males), and 16 healthy individuals (eight females, eight males); serum adiponectin, apelin, resistin levels, fasting and postprandial blood glucose, insulin resistance markers, and lipid parameters were measured. Results: In the study, serum apelin levels were determined to be significantly lower in IGT, MeS, and T2DM groups compared with the control group ( $p=0.002, p=0.006$, and $p<0.001$, respectively). Serum resistin levels were determined to be significantly higher in IGT and T2DM groups compared with the control group ( $\mathrm{p}<0.001$ and $\mathrm{p}<0.001$, respectively).

Conclusions: Apelin and resistin are thought to affect glucose metabolism and insulin resistance. Apelin is an important indicator in individuals with IGT in the prediabetic period and may play a role in preventing diabetic complications and treatment of T2DM. (Endokrynol Pol 2020; 71 (4): 319-324)

Key words: metabolic syndrome; pre-diabetes; apelin; resistin
\end{abstract}

\section{Introduction}

Diabetes mellitus (DM) is a chronic metabolic disease with acute and chronic complications, and high morbidity, mortality, and cost to society [1]. Insulin resistance means that the normal concentration of insulin produces less biological response than normal and the effect of stimulating glucose use is reduced [2, 3]. Genetic factors play an important role among the determinants of insulin sensitivity, and various gene defects are increasing in number $[4,5]$.

The first studies about resistin show that this expression is high in obese animal models and that the level of circulating resistin is associated with insulin resistance in rodents. Resistin is thought to act as a hormone working as an insulin antagonist, effective in glucose metabolism [6, 7]. It was observed that the risk of developing type 2 diabetes (T2DM) also increased in individuals with high levels of resistin and with central obesity $[8,9]$.

Resistin regulates adipocyte metabolism in mice and humans [10]. One of the mechanisms of action of thiazolidinedione (TZD), an antidiabetic drug used in the treatment of T2DM, which is known to reduce insulin resistance, is that it is reported to decrease insulin resistance by preventing the production of adipocyte-induced resistin [8]. This information shows that the increase in circulating resistin is closely related to insulin resistance and hyperglycaemia $[6,8,11]$.

Apelin regulates adipogenesis, fatty acid oxidation, and insulin secretion in DM, and apelin-activated mechanisms play a role in the pathogenesis of DM complications. Apelin improves insulin sensitivity, stimulates glucose use in different tissues linked to DM, and improves brown adipogenesis. In addition, apelin corrects DM-induced kidney hypertrophy, normalises obesity-associated cardiac hypertrophy, and negatively regulates retinal angiogenesis in diabetic retinopathy [12]. Apelin has been described as an increasing new adipokine in obese and hyperinsulinaemic humans and mice. A positive correlation has been reported between plasma apelin levels and BMI. Apelin inhibits insulin secretion in mice, and it is thought to have an important role in regulating glucose homeostasis. However, the 
mechanism of inhibitory effects of apelin on insulin secretion is not fully known [13]. According to the study of Gourdy et al., in humans, injecting high-dose (30 nmol/kg-[pyr1]-apelin-35 13) apelin, the apelin increased insulin sensitivity and the apelin/APJ pathway in patients with T2DM, confirming that it should be considered as a new target for designing alternative therapeutic strategies to control [14].

In this study, we aimed to investigate the levels of apelin and resistin along with biochemical parameters that reflect glucose metabolism in both $\mathrm{MeS}$ and T2DM, and impaired fasting glucose (IFG) and impaired glucose tolerance (IGT), which are pre-diabetic stages.

\section{Material and methods}

\section{Study design and population}

This cross-sectional study was conducted in the internal medicine outpatient clinic of a tertiary university hospital between June 2011 and January 2012. Ethical approval was obtained from the Ethics Committee of Non-Interventional Research of Firat University (12.10.2010/11.11). Those who met the inclusion criteria were included in the study, and written consent was obtained from all participants.

The study inclusion criteria were as follows: (i) having T2DM diagnosis according to 1999 World Health Organisation (WHO) diagnostic and classification criteria; (ii) being over 30 years old; and (iii) having IFG and IGT. On the other hand, the exclusion criteria were: (i) having type 1 diabetes mellitus; (ii) having chronic hypertension disease; (iii) having congenital anomaly, liver disease, chronic renal disease, acute infection, or hypothyroidism; (iv) having malignancy; (v) having psychiatric and neurological diseases that affect cognitive functions; and (vi) having insulin and oral anti-diabetic treatment.

A total of 88 participants matched by age and gender were included in the study. The study was planned with five groups of participants. Study groups were designed as group 1 (control group, $\mathrm{n}=16$ ), group 2 (patients with IFG, $\mathrm{n}=18$ ), group 3 (patients with impaired glucose tolerance, $n=18$ ), group 4 (patients with metabolic syndrome [MeS], $\mathrm{n}=18$ ), and group 5 (newly diagnosed T2DM patients, $\mathrm{n}=18$ ).

\section{Data collection}

Demographic and biochemical parameters of the participants were questioned in the study. The age and gender of the participants were recorded in the questionnaire form. The anthropometric measurements of the participants, i.e. height, weight, and waist circumference, were measured by the same researcher. The standing height of patients was measured with a $0.1 \mathrm{~cm}$ sensitive linear height scale, and weight in lightweight clothing was measured to the nearest $0.1 \mathrm{~kg}$ with a sensitive digital scale. The waist circumference was measured at minimal inspiration to the nearest $0.1 \mathrm{~cm}$, midway between the last rib and the iliac crest. Body mass index (BMI) was calculated by dividing body weight by the square of the height $\left(\mathrm{kg} / \mathrm{m}^{2}\right)$. The blood pressure of all participants was measured with an aneroid sphygmomanometer from both arms after a rest period of at least 15 minutes, then the mean blood pressure was recorded.

\section{Biochemical investigations}

From all patients, whole blood samples (total $5 \mathrm{~mL}$ ) were obtained by venepuncture from a peripheral vein, avoiding haemolysis, into plain tubes. Patients were in a resting position in the morning hours after an overnight fast. Fasting plasma glucose (FPG), high- density lipoprotein cholesterol (HDL-C), low-density lipoprotein cholesterol (LDL-C), and very low-density lipoprotein (VLDL-C), triglycerides (TG) were analysed using an automatic biochemical analyser (FUJI DRI-CHEM 4000i, Fuji, Japan). Samples were taken from the participants for the measurement of postprandial blood glucose. Postprandial blood glucose samples were taken two hours after eating. Haemoglobin $\mathrm{A}_{1 \mathrm{c}}\left(\mathrm{Hb}_{1 \mathrm{c}}\right)$ concentration was measured using the VARIANT II system (Bio-Rad Laboratories, Inc., Hercules, CA, USA).

\section{Measurement of serum resistin levels}

Serum resistin levels were studied in accordance with the kit procedure using the human resistin enzyme-linked immunosorbent assay (ELISA) kit (Millipore, catalogue number: EZHADP-51K, Missouri, USA). Absorbances were read spectrophotometrically on an ELX800 ELISA reader. In plate washings, Bio-tek ELX50 was used as an automatic washer. The test results are multiplied by 10 because of a 1:10 dilution and are indicated in $\mathrm{ng} / \mathrm{mL}$. Kit sensitivity: $<0.16 \mathrm{ng} / \mathrm{mL}$, measurement range: $0.16-20 \mathrm{ng} / \mathrm{mL}$.

\section{Measurement of serum apelin levels}

Serum apelin levels were studied in accordance with the kit procedure using the human apelin enzyme immunoassay kit (Phoenix, catalogue no: EK-057-23). Absorbances were read spectrophotometrically on an ELX800 ELISA reader. In plate washings, Bio-tek ELX50 was used as an automatic washer. Test results are stated in $\mathrm{ng} / \mathrm{mL}$. Kit measurement range: $0.07-100 \mathrm{ng} / \mathrm{mL}$.

\section{Statistical analysis}

Statistical analysis of the data was performed using the IBM SPSS 22 statistics package program. The Shapiro-Wilk test was used to determine whether the data showed normal distribution. Descriptive statistics of the data were expressed as mean \pm standard deviation for variables with normal distribution in continuous data (median [minimum: maximum]) for non-normal distribution variables, and the frequency for categorical variables as percentage ( $\mathrm{n}$ [\%]). Categorical variables were compared using chi-squared tests. In comparison of more than two independent groups, one-way ANOVA and LSD test for post-hoc analysis were used for normally distributed continuous data, and Kruskal-Wallis test and Dunn test for post-hoc test for non-normal distributed continuous data. The significance level was $\alpha=0.05$.

\section{Results}

A total of five groups (four case and one control group) and 88 participants were included in the study. Eighteen newly diagnosed T2DM patients (nine women, nine men), 18 patients with IFG (nine women, nine men), 18 patients with IGT (nine women, nine men), and 18 patients with MeS (nine women, nine men). The control group consisted of 16 healthy individuals (eight women, eight men). When the five groups were compared in terms of age $(p=0.632)$, gender $(p=1.01)$, and height $(p=0.73)$ there was no statistically significant difference between demographic characteristics of groups. There was a statistically significant difference between blood pressure and biochemical parameters between groups (Tab. 1).

Serum apelin levels in T2DM $(0.34 \pm 0.19 \mathrm{ng} / \mathrm{mL})$ $(p<0.001)$, IGT $(0.67 \pm 0.34 \mathrm{ng} / \mathrm{mL})(\mathrm{p}<0.05)$, and MeS $(0.70 \pm 0.43 \mathrm{ng} / \mathrm{mL})(\mathrm{p}<0.05)$, control group 
Table 1. Socio-demographic and biochemical variables of the participants

\begin{tabular}{|c|c|c|c|c|c|c|}
\hline & $\begin{array}{c}\text { Control } \\
(n=16)\end{array}$ & $\begin{array}{c}\text { IFG } \\
(n=18)\end{array}$ & $\begin{array}{c}\text { IGT } \\
(n=18)\end{array}$ & $\begin{array}{c}\text { MeS } \\
(n=18)\end{array}$ & $\begin{array}{c}\text { T2DM } \\
(\mathrm{n}=18)\end{array}$ & $\mathrm{p}$ value \\
\hline Age (years) & $40.94 \pm 5.60$ & $40.28 \pm 4.33$ & $41.44 \pm 4.34$ & $39.17 \pm 4.29$ & $40.94 \pm 4.60$ & $\begin{array}{l}F=0.65 \\
p=0.632\end{array}$ \\
\hline Gender (F/M) & $8 / 8$ & $9 / 9$ & $9 / 9$ & $9 / 9$ & $9 / 9$ & $\begin{aligned} \chi^{2} & =0.045 \\
p & =1.01\end{aligned}$ \\
\hline $\begin{array}{l}\text { Waist circumference } \\
{[\mathrm{cm}]}\end{array}$ & $72.31 \pm 5.25^{*}$ & $89.33 \pm 12.09 *$ & $95.72 \pm 16.5$ & $99.83 \pm 10.53$ & $100.72 \pm 7.74^{*}$ & $\begin{array}{l}F=18.03 \\
p<0.001\end{array}$ \\
\hline Weight [kg] & $68.75 \pm 7.66^{*}$ & $77.67 \pm 11.47$ & $82.56 \pm 15.42$ & $83.72 \pm 11.22$ & $81.00 \pm 8.21^{*}$ & $\begin{array}{l}F=4.79 \\
p=0.002\end{array}$ \\
\hline Height [cm] & $169 \pm 6.62$ & $165 \pm 7.04$ & $166 \pm 8.29$ & $166 \pm 8.3$ & $167 \pm 7.59$ & $\begin{array}{l}F=0.51 \\
p=0.73\end{array}$ \\
\hline BMI $\left[\mathrm{kg} / \mathrm{m}^{2}\right]$ & $24.09 \pm 2.41^{*}$ & $28.35 \pm 4.4^{*}$ & $30.07 \pm 6.45^{*}$ & $30.44 \pm 4.01^{*}$ & $29.26 \pm 2.86^{*}$ & $\begin{array}{l}F=5.86 \\
p<0.001\end{array}$ \\
\hline $\mathrm{FPG}[\mathrm{mg} / \mathrm{dL}]$ & $\begin{array}{c}92.50^{*} \\
(85.0-99.0)\end{array}$ & $\begin{array}{c}111.50^{*} \\
(100.0-125.0)\end{array}$ & $\begin{array}{c}119.00^{*} \\
(100.0-128.0)\end{array}$ & $\begin{array}{c}120.000^{*} \\
(105.0-197.0)\end{array}$ & $\begin{array}{c}203.00^{*} \\
(147.0-315.0)\end{array}$ & $\begin{array}{c}\mathrm{KW}=68.58 \\
\mathrm{p}<0.001\end{array}$ \\
\hline PPG [mg/dL] & $\begin{array}{c}124.00^{*} \\
(105.0-140.0)\end{array}$ & $\begin{array}{c}133,50 \\
(107.0-140.0)\end{array}$ & $\begin{array}{c}187,00^{*} \\
(143.0-203.0)\end{array}$ & $\begin{array}{c}185,50^{*} \\
(141.0-272.0)\end{array}$ & $\begin{array}{c}295,50 \text { * } \\
(180.0-447.0)\end{array}$ & $\begin{array}{c}\mathrm{KW}=72.73 \\
\mathrm{p}<0.001\end{array}$ \\
\hline LDL-C [mg/dL] & $75.0 \pm 14.04^{*}$ & $111.44 \pm 27.52^{*}$ & $132.83 \pm 30.68^{*}$ & $126.06 \pm 26.7^{*}$ & $132.89 \pm 29.9^{*}$ & $\begin{array}{l}F=13.78 \\
p<0.001\end{array}$ \\
\hline VLDL-C [mg/dL] & $\begin{array}{c}21.00^{*} \\
(10.0-31.0)\end{array}$ & $\begin{array}{c}29.00 \\
(14.0-63.0)\end{array}$ & $\begin{array}{c}40.00^{*} \\
(11.0-98.0)\end{array}$ & $\begin{array}{c}43.50^{*} \\
(26.0-77.0)\end{array}$ & $\begin{array}{c}42.50^{*} \\
(13.0-114.0)\end{array}$ & $\begin{array}{c}\mathrm{KW}=29.90 \\
\mathrm{p}<0.001\end{array}$ \\
\hline $\mathrm{HDL}-\mathrm{C}[\mathrm{mg} / \mathrm{dL}]$ & $\begin{array}{c}54.00^{*} \\
(45.0-83.0)\end{array}$ & $\begin{array}{c}45.00^{*} \\
(35.0-52.0)\end{array}$ & $\begin{array}{c}48.00^{*} \\
(29.0-62.0) \\
\end{array}$ & $\begin{array}{c}38.00^{*} \\
(31.0-49.0)\end{array}$ & $\begin{array}{c}36.00^{*} \\
(28.0-42.0)\end{array}$ & $\begin{array}{c}\mathrm{KW}=46.48 \\
\mathrm{p}<0.001\end{array}$ \\
\hline $\begin{array}{l}\text { Triglycerides } \\
{[\mathrm{mg} / \mathrm{dL}]}\end{array}$ & $\begin{array}{c}105.50^{*} \\
(52.0-140.0)\end{array}$ & $\begin{array}{c}145.00 \\
(68.0-314.0)\end{array}$ & $\begin{array}{c}200.50^{*} \\
(54.0-497.0)\end{array}$ & $\begin{array}{c}218.00^{*} \\
(129.0-389.0)\end{array}$ & $\begin{array}{c}215.00^{*} \\
(66.0-571.0)\end{array}$ & $\begin{array}{c}\mathrm{KW}=31.62 \\
\mathrm{p}<0.001\end{array}$ \\
\hline $\mathrm{HbA}_{1 \mathrm{c}}(\%)$ & $\begin{array}{c}4.95^{*} \\
(4.4-5.7)\end{array}$ & $\begin{array}{c}5.75^{*} \\
(4.8-6.5)\end{array}$ & $\begin{array}{c}6.40^{*} \\
(5.6-7.5)\end{array}$ & $\begin{array}{c}6.00^{*} \\
(4.7-7.2)\end{array}$ & $\begin{array}{c}8.40^{*} \\
(6.6-11.6)\end{array}$ & $\begin{array}{c}\mathrm{KW}=62.70 \\
\mathrm{p}<0.001\end{array}$ \\
\hline $\mathrm{SBP}$ [mm Hg] & $117.19 \pm 4.46^{*}$ & $123.33 \pm 4.2^{*}$ & $129.72 \pm 6.52^{*}$ & $132.5 \pm 5.49^{*}$ & $133.06 \pm 8.25^{*}$ & $\begin{array}{l}F=21.55 \\
p<0.001\end{array}$ \\
\hline $\mathrm{DBP}$ [mm Hg] & $77.81 \pm 4.46^{*}$ & $84.17 \pm 5.22^{*}$ & $88.61 \pm 6.14^{*}$ & $93.89 \pm 4.71^{*}$ & $92.5 \pm 7.12^{*}$ & $\begin{array}{l}F=22.84 \\
p<0.001\end{array}$ \\
\hline
\end{tabular}

*Groups with statistical differences between them; T2DM — type 2 diabetes mellitus; F — one-way ANOVA test; KW — Kruskal-Wallis test; IFG — impaired fasting glucose; IGT — impaired glucose tolerance; BMI — body mass index; FPG — fasting plasma glucose; PPG — postprandial glucose; LDL-C — low-density lipoprotein cholesterol; VLDL-C — very low-density lipoprotein cholesterol; HDL-C — high-density lipoprotein cholesterol; $\mathrm{HbA}_{1 \mathrm{c}}$ — glycated haemoglobin; SBP — systolic blood pressure; DBP — diastolic blood pressure

Table 2. Serum apelin levels in the studied groups

\begin{tabular}{|c|c|c|c|c|c|c|c|c|}
\hline & $\begin{array}{c}\text { Control } \\
(n=16)\end{array}$ & $\begin{array}{c}\text { IFG } \\
(n=18)\end{array}$ & $\begin{array}{c}\text { IGT } \\
(n=18)\end{array}$ & $\begin{array}{c}\text { MeS } \\
(n=18)\end{array}$ & $\begin{array}{c}\text { T2DM } \\
(\mathrm{n}=18)\end{array}$ & $\mathbf{p}^{*}$ value & \multicolumn{2}{|c|}{$\mathrm{p}^{* *}$ value } \\
\hline \multirow{5}{*}{$\begin{array}{l}\text { Apelin } \\
{[\mathrm{ng} / \mathrm{mL}]}\end{array}$} & \multirow{5}{*}{$1.01 \pm 0.30^{\mathrm{a}}$} & \multirow{5}{*}{$0.91 \pm 0.22^{b}$} & \multirow{5}{*}{$0.67 \pm 0.34^{c}$} & \multirow{5}{*}{$0.70 \pm 0.43^{d}$} & \multirow{5}{*}{$0.34 \pm 0.19^{\mathrm{e}}$} & \multirow{5}{*}{$\begin{array}{l}F=11.96 \\
p<0.001\end{array}$} & a-b: 0.367 & b-d: 0.050 \\
\hline & & & & & & & a-c: 0.002 & b-e: $<0.001$ \\
\hline & & & & & & & a-d: 0.006 & c-d: 0.761 \\
\hline & & & & & & & a-e: $<0.001$ & c-e: 0.002 \\
\hline & & & & & & & b-c: 0.024 & d-e: 0.001 \\
\hline
\end{tabular}

${ }^{*}$ multiple comparison $\mathrm{p}$ value; **binary comparison $\mathrm{p}$ value; IFG — impaired fasting glucose; IGT — impaired glucose tolerance; MeS — metabolic syndrome; T2DM - type 2 diabetes mellitus

$(1.01 \pm 0.30 \mathrm{ng} / \mathrm{mL})$ was significantly higher compared to. Apelin levels in the T2DM $(0.34 \pm 0.19)$ group, IFG group $(0.91 \pm 0.22 \mathrm{ng} / \mathrm{mL})(\mathrm{p}<0.001)$, IGT group $(0.67 \pm 0.34 \mathrm{ng} / \mathrm{mL})(\mathrm{p}<0.01)$ and MeS group $(0.70 \pm 0.43 \mathrm{ng} / \mathrm{mL})(\mathrm{p}<0.05)$ compared to significantly lower (Tab. 2). 
Table 3. Serum resistin levels in the studied groups

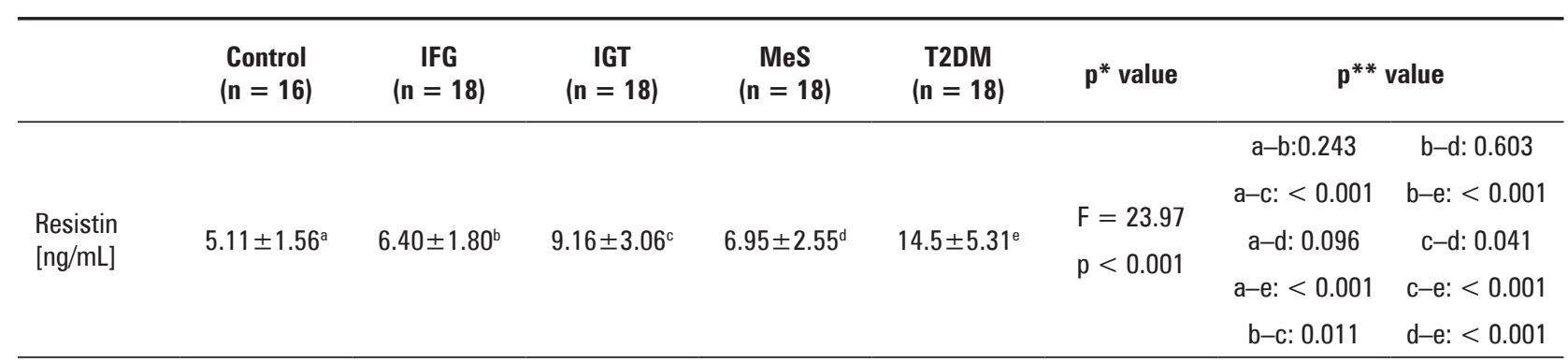

${ }^{*}$ multiple comparison p value; **binary comparison p value; IFG — impaired fasting glucose; IGT — impaired glucose tolerance; MeS — metabolic syndrome; T2DM - type 2 diabetes mellitus

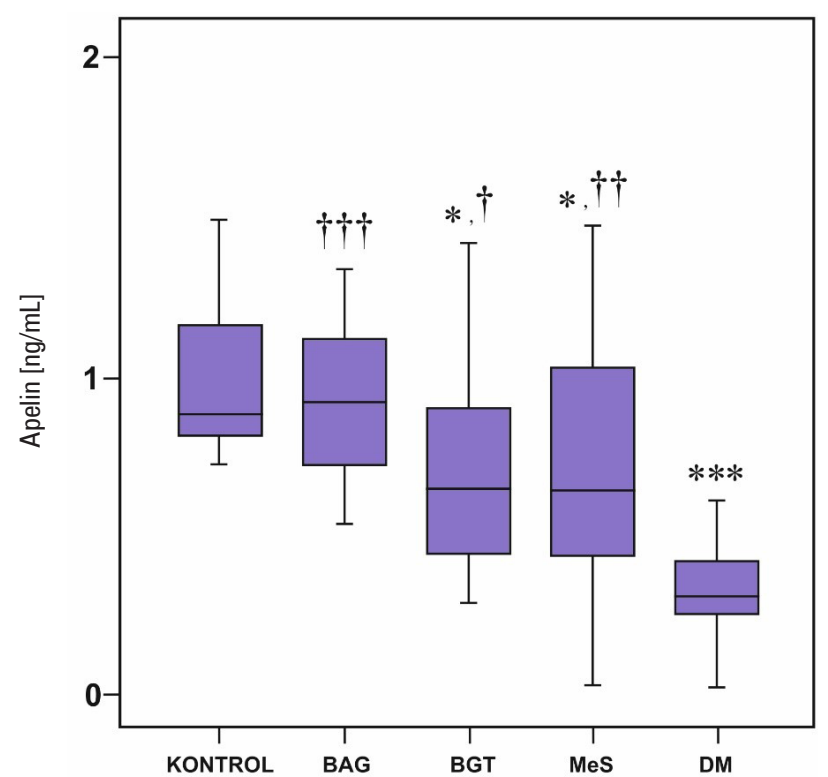

Figure 1. Serum apelin levels belonging to the groups. ${ }^{*} p<0.05$, compared to the control group; ${ }^{* *} p<0.001$, compared to the control group; $t p<0.05$, compared with T2DM group; $t+p<0.01$, compared with T2DM group; $+t+p<0.001$, compared with the T2DM group

Serum resistin levels were significantly higher in the T2DM (14.5 $\pm 5.31 \mathrm{ng} / \mathrm{mL})$ and IGT group $(9.16 \pm 3.06$ $\mathrm{ng} / \mathrm{mL})$ compared to the control group $(5.11 \pm 1.56$ $\mathrm{ng} / \mathrm{mL})(\mathrm{p}<0.001$ and $\mathrm{p}<0.01$, respectively). Resistin levels in the T2DM $(14.5 \pm 5.31 \mathrm{ng} / \mathrm{mL})$ group; IFG $(6.40 \pm 1.80 \mathrm{ng} / \mathrm{mL})$ was significantly higher compared to the IGT $(9.16 \pm 3.06 \mathrm{ng} / \mathrm{mL})$ and MeS $(6.95 \pm 2.55$ $\mathrm{ng} / \mathrm{mL})$ groups $(\mathrm{p}<0.001)$ (Tab. 3).

\section{Discussion}

Diagnosis and intervention in the pre-diabetes stages are important for the prevention of diabetes and its complications. Therefore, this study was planned to determine the levels of a group of adipokines expressed in the adipose tissues of patients with IFG, IGT,

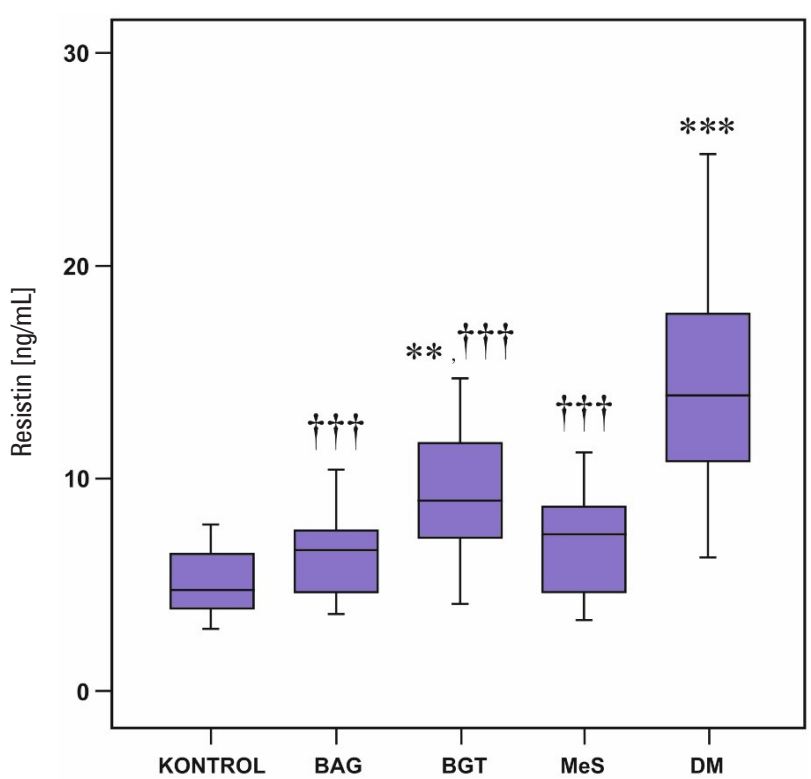

Figure 2. Serum resistin levels of the groups; ${ }^{* *} p<0.01$, compared to the control group; ${ }^{* *} p<0.001$, compared to the control group; $++t p<0.001$, compared with the T2DM group

MeS, and T2DM, and to contribute to the diagnosis and treatment in pre-diabetes and early diabetes stages.

Steppan et al. [11] reported in their study in mice that the level of resistin secreted from adipocytes with rosiglitazone, which is an oral antidiabetic, and increased dietary/genetic obesity. This study group found that diet-induced obesity in mice resulted in increased resistin antibody and insulin activity and improved blood sugar. They determined that after recombinant resistin administration to normal mice, there was a deterioration in glucose tolerance and insulin activity. In the same study, it was found that insulin-sensitive glucose intake from adipocytes decreased with resistin application and increased when resistin was inactivated. Therefore, researchers have argued that resistin is a hormone that acts like an insulin antagonist and causes diabetes development in obesity. 
Serum resistin level, which is one of the main parameters of our study, increased significantly in the T2DM group. Resistin serum levels were not significant in the IFG group compared to the control group ( $p=0.243$ ), but the increase in the IGT and MeS groups was found to be statistically significant (Tab. 3). The increase in serum levels of insulin-resistant expression from adipose tissue in IGT, MeS, and T2DM shows that the levels of these peptide hormones increase as a result of increased hyperglycaemia, which constitutes the starting point of our study. It also reveals the theory that these adipokines, which are expressed from adipose tissue, are not a cause but a consequence of diabetes. In the process that progresses towards T2DM, the increase in plasma levels of resistin are probably effective in the development of complications of patients with T2DM by using the same cellular connection pathways as the resistin decreases glucose tolerance and the effect of insulin on cells as the same peripheral signal molecule.

Boucher et al. [15] reported that the synthesis and release of apelin from adipose tissue was stimulated by insulin. In obese subjects, parallel to the increased body fat content and hyperinsulinaemia, an increase in plasma apelin levels and m-RNA expressions of the apelin in adipocytes was determined. This indicates that the synthesis of apelin is induced by obesity and insulin. On the other hand, apelin has been shown to increase glucose utilisation and inhibit insulin secretion $[16,17]$. Yue et al. [18] reported that insulin resistance occurred in mice with total apelin deficiency and an increase in insulin sensitivity by administering apelin to these mice.

In our study, we found serum apelin levels to be low in IGT, MeS ( $p<0.05)$, and T2DM ( $<<0.001)$ compared to the control group. Also, compared with the T2DM group, we determined that the serum apelin levels of BAG ( $p<0.001)$ and MeS and BGT $(\mathrm{p}<0.05)$ groups were significantly higher. However, in terms of serum apelin levels, there was no statistically significant difference between the IFG group and the control group $(p>0.05)$ (Tab. 2). This result supports the view that apelin increases insulin sensitivity. Similar to our study, Zhang et al. [19] found low plasma apelin levels in newly diagnosed T2DM patients in their study in Chinese people. In this study, it was shown that the apelin level was negatively correlated with C-reactive protein (CRP), fasting blood glucose (FBG), $\mathrm{HbA}_{1 \mathrm{c}^{\prime}}$ and the Homeostatic Model Assessment for Insulin Resistance (HOMA-IR) and positive correlated with insulin sensitivity. In conclusion, they reported that the effect of apelin on glucose can indirectly be performed in insulin by adipocyte stimulation in adipocytes. In light of all these findings, we can say the following: early stage prediabetic individuals who can transform into T2DM are also the main metabolic problem insulin resistance.
Impaired fasting glucose and IGT are considered the starting point of all these diabetic disorders. Adipokines such as apelin and resistin released from adipose tissue appear as molecules responsible for the physiopathological mechanisms that affect the process of formation and development of insulin resistance. Due to the late diagnosis of patients with T2DM, mortality due to diabetic diseases increases rapidly all over the world. It is possible to prevent diabetes and its complications by detecting prediabetic cases in the early period.

In this study, we investigated the levels of apelin and resistin along with biochemical parameters that reflect glucose metabolism in both $\mathrm{MeS}$ and T2DM and IFG and IGT, which are pre-diabetic stages. Thus, we tried to reveal how these parameters change and how they affect each other between the insulin resistance and the development of diabetes. In our study, while serum apelin levels were significantly lower in the IGT, T2DM, and MeS groups compared to the control group, resistin levels were significantly higher in the IGT, MeS, and T2DM groups compared to the control group. In the IFG group, no significant difference was found in terms of resistin and apelin levels compared to the control group.

As a result, the glucose metabolism, insulin resistance, and the release of these cytokines secreted from adipose tissue change positively and negatively. We think that changes in the amount of expression of these cytokines in individuals with IFG and individuals with IGT (during pre-diabetes) can be useful markers in early diagnosis and prevention of complications.

\section{References}

1. Onat T, Emerk K, Sözmen EY. İnsan Biyokimyası. Palme Yayıncılık, Ankara 2006: 280-285.

2. Beck-Nielsen $\mathrm{H}$. Clinical disorders of insulin resistance. In: Alberti $\mathrm{K}$, DeFronzo RA, Keen H, Zimmet P. ed. International Textbook of Diabetes Mellitus. John Wiley\&Sons, Chichester 1992.

3. Simonson DC, Rossetti L, Giaccari A. Glucose toxicity. In: Alberti K, DeFronzo RA, Keen H, Zimmet P. ed. International Textbook of Diabetes Mellitus. John Wiley\&Sons, Chichester 1992: 635-667.

4. Yarımay Tevfikoğlu G. Tip 2 Diyabetli Bireylerin Çocuklarında Kan CRP TNF Alfa, İnterlökin 6 ve Resistin Düzeylerinin İnsülin Direnci ile İlişkisi. Karaelmas Üniversitesi Tıp Fakültesi, Çocuk Sağlığı ve Hastalıkları Uzmanlık Tezi, Zonguldak 2010.

5. Gürlek A. İnsülin direncinde genetik faktörler. In: Çorakçı A. ed. Klinik Endokrinoloji, Meta Basım, İzmir 2001: 49-53.

6. Steppan CM, Lazar MA. Resistin and obesity-associated insulin resistance. Trends Endocrinol Metab. 2002; 13(1): 18-23, doi: 10.1016/s1043-2760(01)00522-7, indexed in Pubmed: 11750858.

7. Berger A. Resistin: a new hormone that links obesity with type 2 diabetes. BMJ. 2001; 322: 193, doi: https://doi.org/10.1136/bmj.322.7280.193/c.

8. Meier U, Gressner AM. Endocrine regulation of energy metabolism: review of pathobiochemical and clinical chemical aspects of leptin, ghrelin, adiponectin, and resistin. Clin Chem. 2004; 50(9): 1511-1525, doi: 10.1373/clinchem.2004.032482, indexed in Pubmed: 15265818.

9. Heilbronn LK, Rood J, Janderova L, et al. Relationship between serum resistin concentrations and insulin resistance in nonobese, obese, and obese diabetic subjects. J Clin Endocrinol Metab. 2004; 89(4): 1844-1848, doi: 10.1210/jc.2003-031410, indexed in Pubmed: 15070954

10. Ort T, Arjona AA, MacDougall JR, et al. Recombinant human FIZZ3/resistin stimulates lipolysis in cultured human adipocytes, mouse adipose explants, and normal mice. Endocrinology. 2005; 146(5): 2200-2209, doi: 10.1210/en.2004-1421, indexed in Pubmed: 15705777. 
11. Steppan CM, Bailey ST, Bhat $S$, et al. The hormone resistin links obesity to diabetes. Nature. 2001; 409(6818): 307-312, doi: 10.1038/35053000, indexed in Pubmed: 11201732

12. $\mathrm{Hu} \mathrm{H}, \mathrm{He} \mathrm{Lu}, \mathrm{Li} \mathrm{L}$, et al. Apelin/APJ system as a therapeutic target in diabetes and its complications. Mol Genet Metab. 2016; 119(1-2): 20-27, doi: 10.1016/j.ymgme.2016.07.012, indexed in Pubmed: 27650065.

13. Akcılar R, Turgut S. Apelinin Kardiyovasküler Fonksiyonlar Üzerine Etkileri. Tıp Araştırmaları Dergisi. 2015; 13(3), doi: 10.18827/etad.69886.

14. Gourdy P, Cazals L, Thalamas C, et al. Apelin administration improves insulin sensitivity in overweight men during hyperinsulinaemic euglycaemic clamp. Diabetes Obes Metab. 2017; 20(1): 157-164, doi: 10.1111/dom.13055, indexed in Pubmed: 28681996.

15. Boucher J, Masri B, Daviaud D, et al. Apelin, a newly identified adipokine up-regulated by insulin and obesity. Endocrinology. 2005;
146(4): 1764-1771, doi: 10.1210/en.2004-1427, indexed in Pubmed: 15677759 .

16. Kleinz MJ, Davenport AP. Emerging roles of apelin in biology and medicine. Pharmacol Ther. 2005; 107(2): 198-211, doi: 10.1016/j.pharmthera.2005.04.001, indexed in Pubmed: 15907343.

17. Małyszko J, Małyszko JS, Koźminski P, et al. Apelin and cardiac function in hemodialyzed patients: possible relations? Am J Nephrol. 2006; 26(2): 121-126, doi: 10.1159/000092122, indexed in Pubmed: 16549903.

18. Yue $\mathrm{P}$, Jin $\mathrm{H}$, Aillaud $\mathrm{M}$, et al. Apelin is necessary for the maintenance of insulin sensitivity. Am J Physiol Endocrinol Metab. 2010; 298(1): E59-E67, doi: 10.1152/ajpendo.00385.2009, indexed in Pubmed: 19861585.

19. Zhang Yu, Shen C, Li X, et al. Low plasma apelin in newly diagnosed type 2 diabetes in Chinese people. Diabetes Care. 2009; 32(12): e150 doi: 10.2337/dc09-1146, indexed in Pubmed: 19940213. 